\title{
Fate or Future?-A Discussion of Taishan Pilgrimage around the 19th and 20th Centuries
}

\author{
Fen Tian \\ Taishan University, Tai'an, China \\ Email: susanhai227@163.com
}

How to cite this paper: Tian, F. (2019). Fate or Future?-A Discussion of Taishan Pilgrimage around the 19th and 20th Centuries. Advances in Journalism and Communication, 7, 109-117. https://doi.org/10.4236/ajc.2019.74007

Received: October 7, 2019

Accepted: November 4, 2019

Published: November 7, 2019

Copyright $\odot 2019$ by author(s) and Scientific Research Publishing Inc. This work is licensed under the Creative Commons Attribution International License (CC BY 4.0).

http://creativecommons.org/licenses/by/4.0/

\begin{abstract}
As one of the most sacred mountains in China, Taishan had drawn people's attention near and far to make pilgrimage each year. In the corner of the 19th and 20th centuries, this changed as Christian religion came into Tai' an city at the foot of Taishan. The paper tries to describe what was happening, the result and why, from the aspect of historical description.
\end{abstract}

\section{Keywords}

Taishan, Pilgrimage, 19th and 20th Century

\section{Introduction}

Taishan, as a sacred mountain in China, has attracted people from all over the country to ascend to the top and worship since the very ancient times (the following figures show different aspects of Taishan, Figure 1 is Bixiaci; Figure 2 is Yuhuangding and Figure 3 is the panoramic Taishan). It was described in the History Record that Emperor Shun had been to Taishan to worship and pray which was called Xunshou', meaning the patrol of the whole country. Later on, emperors of different dynasties came to Taishan to Feng and $S^{2}{ }^{2}$ in person or sent imperial official representatives to do so for them. So, people of different social status, all ages and genders had come to Taishan as pilgrims to pay respect, ask for blessings, beg for the recovery of the kinship from illness, and even

${ }^{1}$ Xunshou was recorded in Chinese classic books such as Historical Record, Book of History, etc.

${ }^{2}$ The word Feng and Shan are two Chinese characters, but always combine together to express the sacrificial ceremony held by the ancient emperors. Feng is to build altar on the top of the Taishan to sacrifice and worship the heaven; and Shan is to do this at a small lower place called Sheshou Shan at the foot of Taishan to sacrifice and worship the earth. In traditional Chinese belief, Heaven was regarded as the place where Gods, Goddesses live, and earth was the place when people died they would go under earth to live another life. It was the Yanluo Wang who governed the people after death in underneath. 


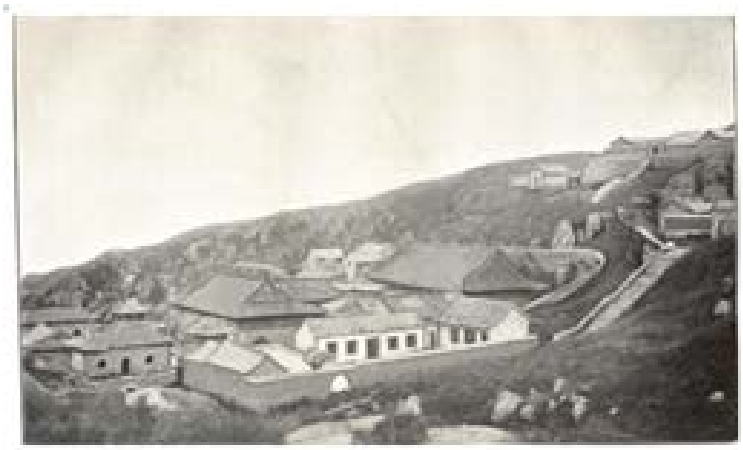

Figure 1. This picture was from Albert Tschepe, 1906.

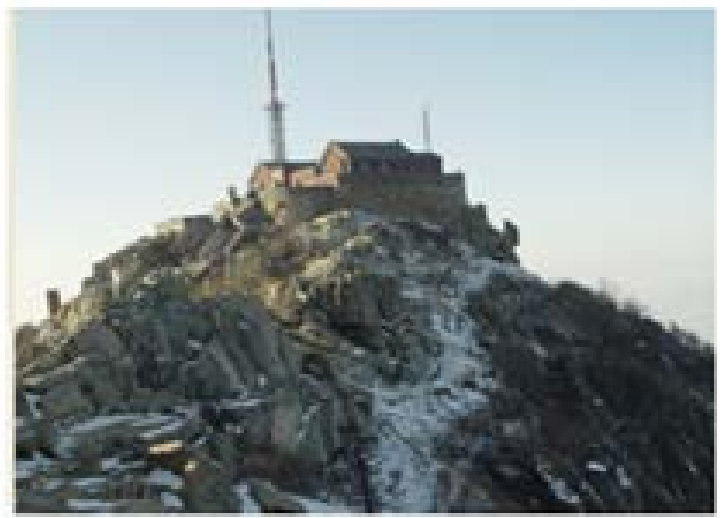

Figure 2. This picture was taken by Wang Kai in 2007.

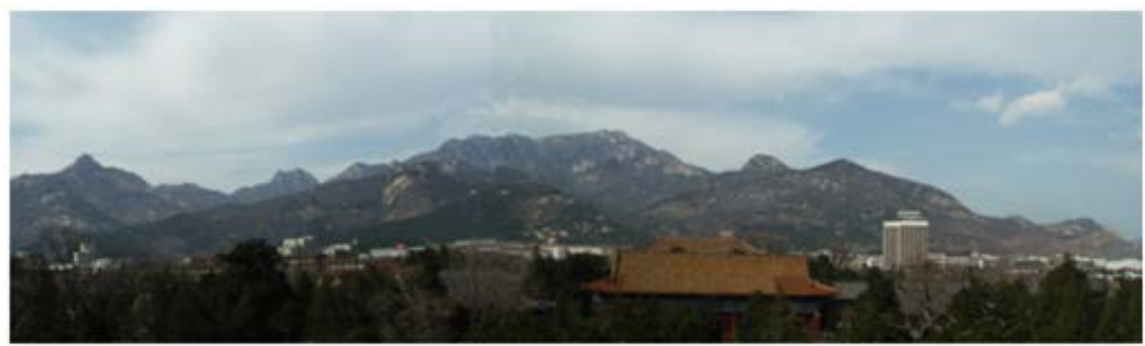

Figure 3. This picture was taken by Wang Kai in 2007.

make enquires for a child especially a boy for the inheritance of the family. This kind of pilgrimage was very popularly developed through dynasties, and for this reason, Taishan was populated with buildings such as shrines and temples all over the mountain from the foot to the top. It was here that Buddhism, Taoism and Confucianism can find their positions and exist harmoniously. All the people who came for different purposes could find their comfort by praying to their Gods or Goddesses. However in the late 19th and early 20th centuries, this kind of harmony changed due to the inburst of missions of various Christian branches, such as the Anglicans and the Society of London. Some people began to turn to the Christian religion, while the most majority especially women remained the traditional Taishan belief. All in all the original Taishan beliefs were under the influence of the western religions. At this time, what would Taishan beliefs 
change? Would the fate of the pilgrims be different? And what was the future of Taishan beliefs? These are questions concerned in this paper, and the rest of the paper is going to focus on answers to these three questions.

\section{The Tradition of Pilgrimage to Taishan}

The tradition of Pilgrimage originated from people's belief that Taishan was the most sacred mountain in China. It was the God of Taishan ${ }^{3}$ who controlled the birth and death of people. It was the Goddess of Taishan who could cure disease. It was the Goddess of Taishan who beheld the happiness and safety of the country and people. Their relationship can be achieved in. Like Zhou Ying (2015) stated "from Ming Dynasty, because of the uprising populace belief in Bixiayuanjun, the belief in Dongyuedadi was ignored"4. So people from all parts of the Shandong province or even from some parts of the country came to ascend Taishan worshipping and praying for rebirth, fortune, happiness, and recovery, etc. Vicar Besi recorded his experience with a group of women, “...the youngest was 78 years and the oldest 99, they had come from the south of Honan, i.e. more than three hundred miles, to remind their god that they had..." ${ }^{5}$ Most of the people were organized by groups called Xianghui (license society) ${ }^{6}$. Generally, Xianghui began to prepare a year before the pilgrimage by collecting money once a month by average share of the members ${ }^{7}$. When everything was ready, the pilgrims would set off by taking wheel-chair, or caravan, some even on foot in the early three lunar months of the new year: February, March and April.

Although called pilgrims in general, they differentiated each other by their social status, genders, ages, etc., each with specific personal purposes ${ }^{8}$. Of them, old women aging from 70 s to 90 s with bound feet were quite popular, like what vicar Besi had stated above9. They ascended and descended the mountain on foot, with the purpose of worshipping before Bixiayunjun, the Goddess of Taishan, to beg a happy life after death (Che, 1991; Dai, 2003; Liu, 1991; Lvg, 1994) ${ }^{10}$. This seemed to be ambiguous, however the fact is that according to beliefs in traditional China, people would live at present and after death. There were three worlds in Taishan, namely heaven after passing through the gate of Nantianmen, ${ }^{3}$ The God of Taishan was also called Taishanshen, Dongyuedadi; and the Goddess of Taishan was always called Bixiayuanjun, Taishan Niangniang, Taishan Nainai, Taishan laomu, etc.

${ }^{4}$ Zhou Ying (2015). The Belief in Bixiayuanjun and Taishan Culture. Shandong People's Publishing House, p 45.

${ }^{5}$ Letter of bishop Besi, apostolic vicar of Shantung to the Directory of the Work. Dated Nanking, May 15th, 1843. Translated from the French in Ann. de la Foi of Sep. 1844. By A.P. Chinese Repository, Vol. 15, 1846.

${ }^{6}$ Arthur Henderson Smith (1845-1932). Village Life in China: A Study in Sociology, New York Chicago Toronto Fleming H. Revell Company, Publishers of Evangelical Literature, 1899.

${ }^{7}$ Ruth Ewing Hanson. A Pilgrim's Confession Women's Foreign Missionary Society. Methodist Episcopal Church Publication Office, Boston, Massachusetts.

${ }^{8} \mathrm{cf}$. Dott, B. (2004). Identity Reflections: Pilgrimages to Mount Tai in Late Imperial China. Cambridge, MA: Harvard University Asia Center, distributed by Harvard University Press.

${ }^{9}$ ibid 6.

${ }^{10}$ The relation between Goddess of Taishan and God of Taishanlies in detailed description, please see Liu, 1991; Lv, 1994; Che, 1991; Dai, 2003. 
the factual world and that of the underneath. And it was the God of Taishan or Taishan Shen or Dongyuedadi in Chinese who controlled the birth and death of the people. After death, people would enter the life underneath with their offspring especially their male ones worshipping before their tablets (as their representatives) usually made of wood. So that is another group of pilgrims, usually women, young or old, ascended Taishan to make requests before Bixiayunjun to beg for a child especially a male child to their family. This was called Shuanwawa in Chinese meaning to take the child back home by the virtue of Bixiayunjun ${ }^{11}$. Still there were other pilgrims came to Taishan for the purpose of saving their kinship from illness by making sacrifices to Taishan. There was once a cliff called Sacrificing Cliff from where people threw their lives down to sacrifice so that the people who were ill would recover. Even it was stupid, the pilgrims believed the magical power from Taishan. And it was recorded a man burned his baby son in order to save the sick parent. This was regarded as filial deed. But later the government built a huge wall before the cliff to prevent this kind of misunderstood Filial piety. Still there were other people wishing to change a better life, so they came to Bixaiyuanjun for help ${ }^{12}$.

Besides, there were literati who ascended Taishan for leaving their works such as calligraphy, poems to record and eulogize that they had been to and Taishan, the sacred mountain ${ }^{13}$. Of which, the most famous poem was Gazing on Taishan by $\mathrm{Du} F u$ in Tang Dynasty.

In the late 19th century to the early 20th century, although the pilgrimage went on as usual, things were changing as the beliefs were under challenging of Christian religion.

\section{The Inburst of Christian Missions}

In 1874, C. P. Scott and M. Greenwood came to China to search for an area as the headquarter to spread Anglican Church under the control of S. P. G. At that time Tai'an and Dongchangfu were not occupied by foreign missions, so they were very happy to make Tai'an the Anglican Center, "This city and its neighborhood appeared to offer peculiar advantages for the establishment of a Mission centre"14. And here at the foot of Taishan, people can listen to the Anglican church like those pilgrims who listened to Apostle Paul delivered the famous speech at Areopagus that the was said to have ${ }^{15}$. In 1878, Tai'an diocese was set up. Later, centers such as Pingyin (1879), Tianjin (1890), Yongqing (1880), Longhuadian (1880), etc. were established. And in 1880, Beijing Diocese was restored ${ }^{11}$ cf. Rev. W. O. Elterich. (1894). A Chinese Goddess-Tai shan Nai Nai or the Mother of Mt. Tai. The Church at Home and Abroad Published Monthly by Order of the General Assembly of the Presbyterian Church in the United States of America. Volume XV, Presbyterian Board of Publication and Sabbath-School Work, No. 1334 Chestnut Street, Philadelphia, PA, p 422.

${ }^{12}$ ibid 8, p 4-5.

${ }^{13}$ ibid 9.

${ }^{14} \mathrm{cf}$. Armstrong (1891). p 126-128.

${ }^{15}$ So here is a hint that Taishan as a sacred mountain, drew the attention of the pilgrims from all over the country is like that of the Areopagus, the sacred place that holy speech was made. 
which included Shandong, Zhili, Henan, Shanxi, Shaanxi and Gansu ${ }^{16}$. In 1912, all the Anglicans from Britain, America and Canada united into a new society called Zhonghuashenghui, with C. P. Scott the first archbishop.

The Methodist Episcopal Church, with the total name Board of Foreign Missions of the Methodist Episcopal Church, was once the biggest church center in Tai'an. The church first came to Anjiazhuang in 1874 under the supervision of Hiram Harrison Lowry ${ }^{17}$. He met Mr. Wang Ruifu who failed the examination in the capital and depressed at that time. Mr. Wang was interested in the church and later he was baptized and went back to his hometown to preach. In 1879, Wilbur C. Longden bought a property at the west of Tai'an city, now it was called Qingnian Road. From then on schools such as kingdergarten, primary school, middle school and high school were built together with Boji Hospital, and Dengyunjie Church. So altogether, Methodist Episcopal Church populated around Tai' an and nearby area. In 1899, there were 7 foreign preachers, 11 Chinese assistants, 845 believers, 21 schools. In 1904, Perry Oliver Hanson (1875-1967) was in charge of the church in Tai'an and extened it into other places such as Dongping, Ziyang, Donge, etc. In 1917, Cuiying Middle School ${ }^{18}$ was formed with Hanson the principal and there were 291 students.

Gospel Baptist Mission was constructed by Tarleton Perry Crawford (1821-1902). He originally belonged to Southern Baptist Convention or Southern Baptist Mission of America which began to be in Shandong Province in September, 1860. In 1863, Mr. and Mrs. Tarlton Perry Crawford ${ }^{19}$ came to Dengzhou to preach. But in 1892, Mr. Crawford held different opinions in church preaching so he led 8 preachers to Tai' an and opened a new church center. They dressed and lived like Chinese, preaching without participating other social activities. In 1894, 12 believers followed. In 1900, due to the Boxers, Mr. and Mrs. Crawford began to retreat and get back to their home via Zhifu under the protection of Yuanshikai. But in 1902, Mrs. Crawford returned to Tai'an with her sister and son-in-law A. G. Jones ${ }^{20}$. After 1909, all the Gospel Baptist Missionaries returned to Southern Baptist Mission of America in Zhifu except Mr. and Mrs. T. L. Blalock (1865-1960) who built a church in Yuanbao Street in 1904. In 1920, the Gospel Baptist Mission changed name into Baptist China Direct Mission, independent from the support from America. It turned out to be successful even in the period

\footnotetext{
${ }^{16} \mathrm{cf}$. Rowan Strong. The Oxford History of Anglicanism, Volume III: Partisan Anglicanism and Its Global Expansion 1829-1914. Oxford University Press, 2017.4.2, Hardcover, ISBN 0199699704 (ISBN13: 9780199699704); https://en.wikipedia.org/wiki/Church_Mission_Society; https://en.wikipedia.org/w/index.php?title=Society_for_the_Propagation_of_the_Gospel_in_Foreig $\underline{\text { n_Parts\&redirect }=\text { no; }}$

https://baike.baidu.com/item/\%E4\%B8\%AD\%E5\%8D\%8E\%E5\%9C\%A3\%E5\%85\%AC\%E4\%BC\%9 A/5018238?fr=aladdin.

${ }^{17}$ Hiram Harrison Lowry (1843-1924). cf. http://blog.sina.com.cn/s/blog_64aaf9330100zxc1.html.

${ }^{18}$ Now Cuiying Middle School was transformed into Tai'an No. 1 High School.

${ }^{19}$ Mrs. Martha Foster Crawford (1830-1909) returned to Tai'an in 1902, a few months after Mr. Crawford passed away.

${ }^{20}$ Alfred George Jones (1846-1905), a famous Baptist in English Baptist Missionary Society. In 1905, he was hit by the collapse of the house in Taishan and died. cf.:

https://en.wikipedia.org/wiki/Alfred_G._Jones.
} 
of 1937-1939, when the Japanese invaded China. In 1940, Mr. Blalock and most of the preachers left Tai'an, and the following year his nephew, the last one, left indicating the end of the church in Tai'an.

Although Gospel Baptist Mission left, their old friend, Mr. Leslie, M. Anglin ${ }^{21}$ (1882-1942) remained. Mr. Anglin came to Tai'an in 1909 under the influence of Mr. Blalock. But in the period of 1911-1912, they had disputes in preaching, so Mr. and Mrs. Anglin bought houses in the eastern part of Tai'an city and began to build Christian church. Later in 1916, the church turned into Home Of Onesiphours with the purpose of doing charity and saving the orphans ${ }^{22}$.

There are still other churches although they didn't choose Tai'an as the center. They had been in Tai'an, climbing Taishan and compiled works to describe, compare and research Taishan cultures including beliefs, traditions, history, sacred figures such as Gods, Goddesses and religious buildings, etc. All in all they were from English Baptist Missionary Society (shortened as BMS) ${ }^{23}$, London Missionary Society ${ }^{24}$, China Inland Mission (shortened as CIM) ${ }^{25}$, American Presbyterian Mission, North) ${ }^{26}$, Congregational Church (or called American Board of Commissioners for Foreign Missions Chinese Repository) ${ }^{27}$, Weimar Mission (or called General Evangelical Protestant Mission) ${ }^{28}$.

Generally, people's thoughts were under influences to some extent. And different beliefs began co-existing for a long period of time.

\section{The Co-Existence of Taishan Beliefs and Christian Religion}

When the foreign missions came to the inland, they would do something to invite the local people as well as the pilgrims. For example, Alexander Williamson recorded "Next day we attended the great fair in the large temple called the Tai Temple, and sold not a few books." ${ }^{29}$ Wilbur C. Longden recorded, "An interesting feature is work among the pilgrims, who come annually in great numbers

${ }^{21}$ cf. https://baike.baidu.com/item/\%E5\%AE\%89\%E4\%B8\%B4\%E6\%9D\%A5/10320371?fr=aladdin

${ }^{22}$ For details please search Zheng Xindao, China Society Press, 2011 (05); Harry James Albus. Twentieth-century Onesphorus: The story of Leslie M. Anglin and the Home of Onesiphorus, 1951.

${ }^{23}$ Representatives are T. M. Morris, Timothy Richard, A. G. Jones, Alexander Williamson (1829-1890), Robert Coventry Forsyth, Samuel Couling, etc.

${ }^{24}$ Representatives are James Legge, Griffith John, etc.

${ }^{25}$ Representatives are Alex Armstrong, Charles Frederick Hogg, etc.

${ }^{26}$ Representatives are John Livingstone Nevius, Rev. J. Fisher Crossette, Calvin Wilson Mateer, Hunter Corbett, Hunter Corbett, Paul David Bergen, Rev. W. O. Elterich, Arthur Judson Brown, etc. cf. https://baike.baidu.com/item/\%E9\%95\%BF\%E8\%80\%81\%E4\%BC\%9A/10587777? fr=aladdin; https://baike.baidu.com/item/\%E7\%BE\%8E\%E5\%9B\%BD\%E9\%95\%BF\%E8\%80\%81\%E4\%BC\%9A/ $\underline{10804633}$;

https://baike.baidu.com/item/\%E7\%BE\%8E\%E5\%8C\%97\%E9\%95\%BF\%E8\%80\%81\%E4\%BC\%9A/ 787473 ?fr=aladdin;

http://lib.sdsqw.cn/bin/mse.exe?seachword=\%u5B97\%u6559\&K=a\&A=79\&rec=176\&run=13

${ }^{27}$ Representatives are Samuel Wells Williams, Arthur Henderson Smith, Charles Alfred Stanley Jr., etc.

${ }^{28}$ Representatives are Richard Wilhelm, etc.

${ }^{29}$ Alexander Williamson (1829-1890) (1870). Ourneys in North China, Manchuria, and Eastern Mongolia; with Some Account of Corea. Smith, Elder \& Co., London, p 431. 
to Tai-an-fu during the first three months. The form this work takes is daily preaching and bookselling by the Tai' an pastors, assisted at intervals by the other pastors and preachers. Very many of these pilgrims are well disposed toward Gospel ... that a far-reaching and potent influence for good results from it." 30 And Methodist Episcopal Church would set up tents in the entrance or in Dai Temple, Mrs. Hanson recorded, "Presently they discovered a white tent from which women came and went at their own pleasure. Mrs. Chao went up to see what might be inside. She was somewhat disappointed to find only benches within and groups of women sitting about drinking tea." ${ }^{31}$ And they would depend on the local preachers to invite more people such as old Mrs. Wang's contribution $^{32}$ to Methodist Episcopal Church. So under the influence, pilgrims to Taishan began to change.

Some would reject severely, the missionaries have met with oppressions and obstacles from the local people and societies such as Big-knife and Boxers. In 1887, rumor was that the foreigner was bullying and stealing, and people who rented the house to them were bad. They even issued the foreigners to the local Yamen, the governmental court. In December 1899, Sidney Brooks was murdered by the Boxers. Chen Hengte of Methodist Episcopal Church had recorded that, "An-chia-chuang is one of the oldest stations and had formerly a membership of over two hundred. At the time of the Boxer uprising many of the members could not endure the persecutions which arose and went back into the world, so that the church membership was reduced to between sixty and seventy." 33

Some made use of it, and became missionaries and benefited. At that time when pilgrims worshipped Gods and Goddesses for help but in vain, they would change and turn to Churches. For example, Francis W. Verity recorded, “... at the foot of the sacred Tai mountain, whither so many pilgrims resort, and it is interesting to hear relate her conversations with them. One poor old devotee of seventy has walked twenty-five miles, and climbed the lofty mountain every year for ten years, but confessed that she had not yet found the peace and happiness for which she so deeply longed. Earnestly she listened as ..." ${ }^{\prime 34}$

Some turned to churches and became preachers, assistants or believers. For examples, "The district of Xintai, sixty miles south east of Tai'an, was the first to be entirely the responsibility of a Chinese priest, John Kao. He had seven catechists and twelve schoolmasters working with him in none village centers, each of ${ }^{30}$ Minutes of the Sixth Session of the North China Annual Conference of the Methodist Epical Church, Oct. 5th-10th, 1898, p 44

${ }^{31}$ ibid 8, p 13-14.

${ }^{32}$ Minutes of the Eighth Session of the North China Annual Conference of the Methodist Epical Church. May 31st-June 3rd, 1900; Official Minutes of the Tenth Session of the Woman's Annual Conference of Methodist Epical Church in North China, June 19-21, 1902; Official Minutes of the Tenth Session of the Woman's Annual Conference of Methodist Epical Church in North China, June 19-21, 1902, p 49-50. Official Minutes of the Tenth Session of the Woman's Annual Conference of Methodist Epical Church in North China, June 19-21, 1902, p 47-48; North China Woman's Conference of Methodist Epical Church in North China, 1903, p 42, p 53-55.

${ }^{33}$ Official Minutes of the Tenth Session of the Woman's Annual Conference of Methodist Epical Church in North China, June 19-21, 1902, p 38-39.

${ }^{34}$ Methodist Episcopal Church. North China Woman's Conference, 1902, p 47. 
which had a church school. A new center was opened at Tungchang, about twenty-three miles north-west of Pingyin, in 1915. Timothy Hsi was priest-in-charge here. He was regarded by some as the ablest of the Chinese clergy." 35

Some were just witnessing what was going on but did not change their original beliefs. They looked on the foreigners as somebody interesting. They would not turn to churches, such as Mrs. Hanson ${ }^{36}$ mentioned Mrs. Chao would not turn to church.

Later, after this period, especially in the period of Japanese Invasion, people's thoughts rearranged: some gave up the missions; some insisted on and some joined the army influenced by the advanced thoughts, many students from Cuiying Middle School turned to revolution to join the army.

\section{Discussions of the Results}

During the period, pilgrims were influenced by Christian religion, and some turned to churches. This period is a co-existing of foreign belief and traditional Taishan Beliefs.

This can be clearly depicted in Mrs. Hanson's record. She described several women's pilgrimage in a small village called Han Village. In it, several women: old Mrs. Han, young Mrs. Han, Mrs. Chao, Mrs. Zhang Mrs. Wu, etc. planned to go to Taishan worshipping, each with their own respective vow to make ${ }^{37}$. Mrs. Zhang wanted to thank Taishan for bringing good crops and life; $\mathrm{Mr}$. Wu longed to beg a boy child for her son; Mrs. Chao wanted to enjoy; Old Mrs. Han was old, she had been to Taishan before and now wanted to prepare for the rebirth; young Mrs. Han wanted to change life. They made preparations before setting off and after the pilgrimage they went to the Dongyue Fair held in Dai Temple at the foot of the mountain where they met a Christian tent. Mrs. Chao saw, enjoyed and then left. She would not accept foreign religion. She was a typical representative of the majority of Chinese pilgrims who formed deep-rooted traditional beliefs refusing to take in new thoughts. However young Mrs. Han would turn to churches. WHY? The answer is that young Mrs. Han had suffered and was suffering misery from life; she could not find any help. She felt extremely hopeless. So at this time, when a new thought came to her, she would feel comfortable, fresh and improved in spirit and soul. Similarly, when the traditional belief could not satisfy the needs or couldn't comfort people at that time, they would change beliefs. This seems to be very practical, however it is the truth; also as Alex. Armstrong recorded, "In one of these villages, a temple of three Pu-sas and to the Goddess of Taishan, was cleared of about fifty idols, by the voluntary act of the villagers, under the lead of the keeper of the temple, who was an inquirer into Christian truth. All these divinities were taken out and buried darkly at dead of night in a gutter, and the buildings were turned into a Christian chapel." ${ }^{38}$

\footnotetext{
${ }^{35} \mathrm{cf}$. G. F. S. Gray. Anglicans in China A History of the Zhonghua Shenggong Hui (Chung Hua Sheng Kung Huei). The Episcopal China Mission History Project, 1996, p 37. 
Later, when the Japanese invaded, most people gave up the Christian belief. And their future lies in what can bring hope and happiness. So the fate would go with the future.

Due to time and format, this paper has to be concluded. This is a historical record of changes in Taishan Beliefs under the influence of foreign thoughts. What the paper wants to make clear is to describe what was happening at that time.

\section{Supported}

This work was supported by the 2019 Special Projects of Social Science Planning Project in Shandong Province under Grant No. 19CWZJ47 (2019 年度山东省社 会科学规划研究专项立项).

\section{Conflicts of Interest}

The author declares no conflicts of interest regarding the publication of this paper.

\section{References}

Che, X. L. (1991). The Mythical Belief in the Goddess of Taishan and Religion. In Taishan Research Series (III). Qingdao: Qingdao Ocean University Press.

Dai, H. L. (2003). The Space of Social Memory-Based on Bixiayuanjun Belief in Shandong in the Qing Dynasty. Journal of University of Jinan (Social Science Edition), 3, 31-37.

Liu, H. (1991). Taishanshen: The Origin of Dongyuedadi and the Cultural Characteristics. In Research Series of Taishan (III). Qingdao: Qingdao Ocean University Press.

Lv, J. X. (1994). The Development of Dongyuedadi Belief and Its Cultural Connotation. Chinese Populace Culture: Gods Beliefs in the Populace. Shanghai: Academia Press. 